\title{
The Ethics of Killing in War
}

\author{
Jeff McMahan
}

Published online: 4 August 2006

(C) Springer Science + Business Media B.V. 2006

\begin{abstract}
This paper argues that certain central tenets of the traditional theory of the just war cannot be correct. It then advances an alternative account grounded in the same considerations of justice that govern self-defense at the individual level. The implications of this account are unorthodox. It implies that, with few exceptions, combatants who fight for an unjust cause act impermissibly when they attack enemy combatants, and that combatants who fight in a just war may, in certain circumstances, legitimately target noncombatants who bear a significant degree of moral responsibility for a wrong, when the prevention or rectification of that wrong constitutes a just cause for war.
\end{abstract}

Keywords just war law of war-self-defense - proportionality · jus ad bellum - jus in bello . just combatant $\cdot$ unjust combatant

\section{The Traditional Theory of the Just War}

The traditional theory of the just war comprises two sets of principles, one governing the resort to war (jus ad bellum) and the other governing the conduct of war (jus in bello). The two set of principles are regarded, in Michael Walzer's words, as "logically independent. It is perfectly possible for a just war to be fought unjustly and for an unjust war to be fought in strict accordance with the rules." (Walzer, 1977, p 21) ${ }^{1}$ Let us say that those who fight in a just war are just combatants, while those who fight in a war that is unjust because it lacks a just cause are unjust combatants. (A just cause is an aim that can contribute to the justification for war and that may permissibly be pursued by means of war.) The most important implication of the idea that jus in bello is independent of jus ad

\footnotetext{
${ }^{0}$ Compare Henry Sidgwick's claim that "the rules which civilised opinion should attempt to impose on combatants...must abstract from all consideration of the justice of the war." (Sidgwick, 1891, pp 253-254)
}

This is an abridged version of a paper that originally appeared in Ethics 114 (2004): $693-733$. (C) 2004 by The University of Chicago Press. All rights reserved. I am grateful to the publisher, the University of Chicago Press, for granting me permission to reprint this material here. Acknowledgments of my intellectual debts appear in the original version.

J. McMahan $(\bowtie)$

Department of Philosophy, Rutgers University, New Brunswick, NJ 08901-1411, USA

e-mail: momahan@philosophy.rutgers.edu 
bellum is that it makes no difference to the permissibility of an unjust combatant's conduct in war that he fights without a just cause. Unjust combatants do not do wrong merely by participating in an unjust war. They do wrong only if they violate the principles of jus in bello. So the moral position of unjust combatants is indistinguishable from that of just combatants - a condition that Walzer refers to as "the moral equality of soldiers" (Walzer, 1977, p 34). Both just and unjust combatants have "an equal right to kill" (Walzer, 1977, p 41).

They do not, of course, have a right to kill just anyone. According to the traditional theory, combatants are permitted to kill only opposing combatants. This is, indeed, the traditional understanding of the central requirement of jus in bello: the requirement of discrimination. All combatants, just and unjust alike, must discriminate between combatants and noncombatants, intentionally attacking only the former and not the latter.

In this paper I will challenge all three foundational tenets of the traditional theory I have identified: (1) that the principles of jus in bello are independent of those of jus ad bellum, (2) that unjust combatants can abide by the principles of jus in bello and do not act wrongly unless they fail to do so, and (3) that combatants are permissible targets of attack while noncombatants are not. I will begin by examining certain arguments that have been offered in support of these tenets. I will then argue that the tenets cannot be correct. Finally, I will sketch the outlines of a revisionist understanding of the just war that I believe is more consistent and plausible, as well as better grounded, than the traditional theory.

\section{The Presumed Permissibility of Defensive Force}

According to the traditional theory, we are all initially "morally immune" to attack. Those who do nothing to lose their right against attack are commonly said to be innocent. Yet, as Thomas Nagel observes, in the tradition "“innocent' means 'currently harmless,' and it is opposed not to 'guilty' but to 'doing harm"” (Nagel, 1985, p 69). Those who retain their immunity to attack are therefore those who are not threatening. In the context of war, the innocent are those who do not contribute to the prosecution of the war - that is, noncombatants. The noninnocent are those who pose a threat to others - that is, combatants. They lose their immunity and are liable to attack.

These observations help to reveal how the three tenets of the traditional theory follow from a general principle of the permissibility of defensive force. Because just combatants threaten unjust combatants, they are noninnocent and lose their right not to be attacked. For "that right," according to Walzer, "is lost by those who bear arms 'effectively' because they pose a danger to other people" (Walzer, 1977, p 145). It does not matter that they have done no wrong: "Simply by fighting," just combatants lose "their title to life and liberty, ...even though, unlike aggressor states, they have committed no crime" (Walzer, 1977, p 136). This is why unjust combatants do no wrong in attacking them. But just combatants are also permitted, for the same reason, to attack the unjust combatants who threaten them. The fact that just combatants fight in a just war while unjust combatants do not is irrelevant to their respective justifications for fighting; hence the independence of jus in bello from jus ad bellum. Finally, the distinction between combatants and noncombatants is significant because combatants pose a threat and so may be the target of defensive force, while noncombatants do not pose a threat and thus cannot be the target of defensive force (though of course they can be used instrumentally in defensive efforts directed against threats posed by others). 
The attempt to ground the tenets of just war theory in the permissibility of defensive force cannot succeed, however, because it is simply false that all defensive force is permissible. Consider a case at the individual level of a surprise attack. Suppose a villain attacks you, entirely without justification or excuse, but that the initial attack fails to overcome you. Rightly believing that he will otherwise kill you, you justifiably attack him in self-defense. If all necessary and proportionate defensive force is permissible, the fact that you now pose a threat to your attacker makes it permissible for him to attack you - even to kill you if your defensive counterattack threatens his life. Hobbes accepted this conclusion, but he was one of the last people to accept it. Most find it impossible to believe that, by unjustifiably attacking you and thereby making it justifiable for you to engage in self-defense, your attacker can create the conditions in which it becomes permissible for him to attack you. Most of us believe that, in these circumstances, your attacker has no right not to be attacked by you, that your attack would not wrong him in any way, and that he therefore has no right of self-defense against your justified, defensive attack (McMahan, 1994a, p 257). But if your attacker has no right of self-defense, then not all defensive force is permissible.

Walzer recognizes this. He implicitly rejects the suggestion that the three foundational tenets of the traditional theory derive from a principle of the permissibility of defensive force. Indeed, he supplies his own counterexample to such a principle: "In the course of a bank robbery, a thief shoots a guard reaching for his gun. The thief is guilty of murder, even if he claims that he acted in self-defense. Since he had no right to rob the bank, he also had no right to defend himself against the bank's defenders" (Walzer, 1977, p 128). ${ }^{2}$ In general, Walzer believes, there is no right to self-defense in the course of criminal activity. And he concedes that "aggression is ... a criminal activity" (Walzer, 1977, p 128). Yet he contends that participation in unjust, aggressive war differs in a morally significant way from participation in domestic criminal activities. In the domestic context, "the idea of necessity doesn't apply to criminal activity: it was not necessary to rob the bank in the first place" (Walzer, 1977, p 128). But the idea of necessity does, he argues, apply to war, and this makes a difference to the morality of participation in an unjust war. "Personal choice," he contends, "effectively disappears as soon as fighting becomes a legal obligation and a patriotic duty. ... For the state decrees that an army of a certain size be raised, and it sets out to find the necessary men, using all the techniques of coercion and persuasion at its disposal" (Walzer, 1977, p 28). Because those who become combatants are subject to a variety of forces that compel their will - manipulation, deception, coercion, their own sense of the moral authority of the government that commands them to fight, uncertainty about the conditions of justice in the resort to war, and so on - they cannot be held responsible for merely participating in an unjust war. As Walzer puts it, "their war is not their crime;" for "the war itself, ...soldiers are not responsible" (Walzer, 1977, pp 37-38).

These claims about the necessity of participation in an unjust war support the contention that such participation differs in permissibility from ordinary criminal activity only if they provide a basis for claiming that participation is justified. But it seems that they are best understood as excuses. They may show that a particular unjust combatant is not a criminal and is not to be blamed or punished for what he does, but they do not show that he acts permissibly. If, however, unjust combatants are at best merely excused for fighting, while just combatants are justified, two of the central tenets of traditional just war theory must be rejected. It is false that unjust combatants do no wrong to fight provided they respect the rules of engagement. And it is false, a fortiori, that jus in bello is independent of jus ad bellum.

\footnotetext{
${ }^{0}$ See also the discussion on Walzer's pp. 38-39.
} 


\section{Are Unjust Combatants Justified in Fighting?}

The best argument of which I am aware for the claim that participation in an unjust war can be morally justified appeals to institutional considerations. There are institutions that are necessary to achieve certain important social goods - for example, coordinated decisionmaking, security, and so on. We therefore have moral reason to support these institutions. But they cannot operate to produce social goods unless people are willing to participate in them even when they require that people do what they believe to be wrong, and may actually be wrong. For example, democratic decision-making may require voting, but voting is pointless unless people will abide by the outcome of the vote, even if it commits them to support policies or participate in activities they believe to be wrong. Similarly, domestic security requires laws that, to be effective, must be enforced. Police, judges, prison officials, and others must therefore enforce the laws, including those they believe, perhaps rightly, to be unjust. For the legal system could not function if individuals were permitted selectively to enforce only those laws they believed to be just.

Similar considerations apply to participation in military institutions. It may be rational both epistemically and practically to establish an institutional division of moral labor that assigns responsibility for important decisions such as whether to go to war to those who have access to the relevant information, are positioned to coordinate an effective response to external threats, and can be held accountable for their decisions. Military institutions themselves may thus demand that only those with the assigned authority should make decisions pertaining to jus ad bellum. If the institutions are to survive and carry out their functions, others within them must fulfill their assigned roles even if they disagree with the decisions reached by those responsible for matters of jus ad bellum.

By participating in such institutions as the legal system and the military, individuals risk becoming instruments of injustice. But if the institutions are sufficiently important, this is a risk that individuals morally ought to take.

This argument, while forceful, cannot vindicate the traditional view that unjust combatants do wrong only if they violate the rules of jus in bello. For it grounds an unjust combatant's justification for fighting in his duty to support certain institutions and in his duties to his fellow participants in these institutions; but these duties arise only in the case of institutions that are genuinely just and important. Thus when unjust combatants are compelled by governments or military organizations that lack legitimacy to fight in wars that lack democratic authorization, they have no institutional obligations that can justify their fighting. According to this argument, therefore, some unjust combatants are justified in fighting while others are not. And this is not what the traditional view claims.

Can the appeal to institutional obligations show that at least some unjust combatants are justified in fighting? It seems clear that there are cases in which such considerations as the importance of an institution in securing social goods, the importance of the individual's contribution to the survival and integrity of the institution, and the individual's obligations to other participants in the institution together make it permissible, all things considered, for the individual to do what would otherwise be wrong, and may be unjust to those who are victims of the action. In such cases, the conflict between the individual's duties is resolved in favor of the institutional duties, though the individual may also be morally required to call attention to and protest against the malfunctioning of the institution.

There are, however, some types of act that are so seriously objectionable that they cannot become permissible even if they are demanded by institutions that are both just and important. For example, while it may be permissible or even obligatory for agents of a legal system that is just overall to enforce an unjust law (especially when people can choose 
whether to accept the risks involved in violating that law), it may not be permissible for them to punish, and would certainly be impermissible for them to execute, a person they know to be innocent of violating the law, even if that is what their institutional role requires. The same is true of the sorts of act required by participation in an unjust war - namely, killing people who have done no wrong, collaborating in the destruction of their political institutions and way of life, and so on. These acts are beyond the limits of what can be made permissible by a person's institutional obligations. This is in part because of the gravity of the harms inflicted; but it is also, and equally essentially, because of the moral status of the victims. Just combatants, in taking up arms in a just cause - most commonly, defense against unjust aggression - do nothing to lose their right not to be attacked or killed or to make themselves morally liable to attack; they are innocent in the relevant sense. Merely posing a threat to the unjust combatants who have attacked them is, as we have seen, not enough to make them liable. So in fighting against just combatants, unjust combatants would be attacking and killing the innocent. It is generally believed to be wrong, except in the direst circumstances, to kill the innocent even as a means of averting a greater evil. How, then, could it be permissible to kill the innocent as a means of achieving aims that are unjust?

It is often suggested that if some soldiers or draftees refuse on moral grounds to fight in an unjust war, this could compromise the efficient functioning and perhaps even threaten the survival of valuable institutions to which these people would rightly be committed. But even if this is true, those who create, serve, and are served by valuable institutions must themselves bear the burdens when those institutions malfunction, thereby causing or threatening unjust harm to others. It would be unjust to impose the costs of their own mistakes or wrongdoing on others.

Yet the consequences for just institutions of people refusing to fight in unjust wars are unlikely to be calamitous. If the refusal to cooperate were sufficiently extensive or widespread, it could seriously degrade the ability of the aggressor (as I will call a country that fights an unjust war) to prosecute the unjust war and could even contribute to its defeat. This might be bad for the aggressor overall, but there are reasons for doubting whether it would be bad for the aggressor's just institutions - and it is just institutions rather than overall national self-interest that is the focus of the argument we are considering. Victory in an unjust war may serve the national interest but is likely on balance to have a corrupting effect on just institutions. Would just institutions in Germany, for example, have benefited from victory in World War II?

\section{Why Jus in Bello Cannot be Independent of Jus Ad Bellum}

Recall that the jus ad bellum requirement of just cause is a constraint on the type of good that may permissibly be pursued by means of war. Just cause is an extrapolation into the domain of war of the insistence that one may not seriously harm or kill another person except for certain highly specific reasons, such as to defend oneself or another against an unjust threat of extreme gravity. Just as one may not kill a person as a means of promoting certain goods, no matter how great those goods would be, so there are many goods - for example, economic growth - that may not be pursued by means of war, no matter how effective war would be in promoting them. ${ }^{3}$

\footnotetext{
${ }^{3}$ Here I draw on the argument in McMahan and McKim (1993), pp. 502-506, 512-513.
} 
I will argue that whether people fighting in a war have a just cause makes a great difference to whether their acts of war can satisfy the jus in bello requirement of proportionality. This requirement holds that for an act of war to be permissible, its bad effects must not be out of proportion to its good effects. Yet, if the requirement of just cause specifies the types of good that may legitimately be pursued by means of war, it is hard to see how, in the absence of a just cause, there can be any goods to weigh against the harms that the acts of unjust combatants cause. For goods that may not legitimately be pursued by means of war cannot contribute to the justification for an act of war and thus cannot figure in the proportionality calculation for that act of war.

There are, however, some goods that combatants may legitimately pursue in the course of war even when their war aims are otherwise unjust. These are the goods that would be secured by preventing just combatants from engaging in acts of war that would be wrong. There are two basic ways in which just combatants may act wrongly in fighting. One is to pursue their just cause by wrongful means - that is, by force or violence that is unnecessary, excessive, disproportionate, or indiscriminate. The other is to pursue a subordinate aim that is unjust within a war that is just overall because its guiding aims are just. As an example of the former, suppose that just combatants were to attempt to coerce the surrender of their opponents by attacking a population of innocent civilians. It would be permissible, if necessary, for unjust combatants to use military force against the just combatants to prevent this. By posing an unjust threat by their own belligerent action, the just combatants would, as I will argue later, make themselves liable to attack. In these circumstances, the good that the unjust combatants' action would achieve - saving the lives of innocents - would weigh against the harm it would cause to the just combatants, thereby making the action proportionate. This, therefore, is an act of war by unjust combatants against just combatants that is proportionate and permissible.

This, however, is of negligible significance for the defense of the traditional theory of the just war. For unjust war cannot consist entirely, or even predominantly, of acts that prevent wrongful acts by just combatants. In practice only a small proportion of the acts constitutive of an unjust war could be of this sort. If this is right, then an unjust war cannot be fought "in strict accordance with the rules." For except in the limited range of cases in which unjust combatants act to prevent wrongful acts by just combatants, their acts of war cannot satisfy the proportionality requirement, and satisfaction of this requirement is a necessary condition of permissible conduct in war. ${ }^{4}$ In general, therefore, unjust combatants cannot participate in war without doing wrong. Since this is not true of just combatants, jus in bello cannot be independent of jus ad bellum. In short, the first two foundational tenets of the traditional theory are mistaken.

If the range of goods that can make the action of unjust combatants proportionate is restricted to the prevention of harms that would otherwise be unjustly inflicted by just combatants, what have just war theorists been assuming when they have claimed that acts of war by unjust combatants can be proportionate in the same way that acts of war of just combatants can? What goods have they thought might weigh against the harms caused?

Sidgwick gives a neutral statement of the requirement of proportionality, one he assumes can be satisfied by just and unjust combatants alike. He states that the "moral combatant" will seek as his end "to disable his opponent, and force him into submission," but that he must not "do him ... any mischief of which the conduciveness to the end is slight in

\footnotetext{
${ }^{4}$ I believe that in the same cases in which they cannot satisfy the requirement of proportionality, unjust combatants also cannot satisfy the requirement of discrimination. But this claim presupposes a conception of the requirement of discrimination different from the orthodox conception. I will defend the alternative conception in the following section.
} 
comparison with the amount of the mischief" (Sidgwick, 1891, p 254). Walzer interprets this passage as claiming that the "mischief" caused by an act of war must be weighed against the act's contribution to "the end of victory" (Walzer, 1977, p 129). And this is the orthodox view: the harm caused must be weighed against the "military value" of the act, which is measured by its contribution to the defeat of the enemy.

But one cannot weigh the bad effects that one would cause against the contribution one's act would make to the end of victory without having some sense of what the good effects of victory would be. Without that, it is hard to see how there can be any constraint at all. One cannot evaluatively weigh the "mischief" caused by an act of war against the contribution the act would make to the probability of a mere event; one must also have some sense of the importance or value of the event. If one's cause is unjust, the value of the event - victory would presumably be negative, not positive. How, for example, could a Nazi soldier weigh the harms he would cause to enemy combatants against the end of victory by the Nazis without assigning any value to that victory? If he believes a Nazi victory would be a great good, he is mistaken.

Perhaps some have assumed that, given the inevitable uncertainties about just cause, it is important to encourage all combatants to exercise restraint by keeping their action proportionate to what they believe will be its good effects. This is indeed plausible but, so understood, the requirement of proportionality is, in its application to unjust combatants, not a genuine moral requirement but merely a device that serves the moral purpose of limiting the violence of those who ought not to be engaged in warfare at all.

Another possibility is that what proportionality requires is just a neutral comparison between the harm an act of war inflicts and that which it averts on the battlefield. It is not concerned with the larger aims of the war at all but weighs the harms inflicted on enemy forces against the magnitude of the threat they pose to one's own forces in combat.

This view does not, however, match most people's intuitions - even though these intuitions favor the view that proportionality is a neutral requirement that can be satisfied or violated by just and unjust combatants alike. Most people believe, for example, that it would be permissible to kill ten enemy combatants (or twenty, or a hundred) to prevent the killing of a single member of one's own forces. This is in part because the threat from enemy combatants is not confined to the threat they pose to one's own forces; they also threaten the aims one has in fighting.

This view is tantamount to the claim that the good to be weighed in the proportionality calculation is the self-preservation of the unjust combatants themselves. But unjust combatants are entitled to weigh the good of their own preservation against the harms they might cause only if this good is one that it is permissible for them to pursue in the circumstances. And the assumption that it is permissible for them to use force even in selfdefense is precisely what I have challenged. Those they have attacked, and who in consequence now threaten them in return, have done nothing to lose their right not to be attacked. Recall that in the individual case a culpable attacker has no right of self-defense against the defensive force of his victim. This should be true of unjust combatants as well unless the circumstances of war fundamentally alter the morality of defensive force. ${ }^{5}$ I

\footnotetext{
${ }^{5}$ In an earlier paper, I claimed that "a case can perhaps be made" for the view that morally innocent unjust combatants can be "justified in engaging in self-defense against the defensive counterattack by the victims of their initial attack" (McMahan, 1994b). Because I now attribute less significance than I did earlier to the distinction between moral innocence and moral culpability, I believe that this earlier claim is mistaken. Two philosophers who have argued persuasively against my earlier position on self-defense by morally innocent unjust combatants against just combatants are Richard Arneson ("Just Warfare Theory and Noncombatant Immunity," manuscript) and McPherson (2004).
} 
believe that the morality of defense in war is continuous with the morality of individual self-defense. Indeed, justified warfare just is the collective exercise of individual rights of self- and other-defense in a coordinated manner against a common threat. ${ }^{6}$

Two further points deserve mention here. First, self-defense by unjust combatants in general fails to meet the necessity requirement for permissible self-defense. They need not kill in order to avoid harm to themselves when they have the option of surrender. They are unjustified in killing in self-defense when they could preserve their lives simply by stopping their own wrongful action.

Second, even if acts of war by unjust combatants could in some instances be proportionate because the goods secured by self-defense would outweigh the harms caused, it remains true that no unjust war could consist entirely in justified acts of individual self- and other-defense. While a series of acts of individual self-defense might in combination count as war, it would in the nature of the case be a just rather than unjust war. Even if there can be just wars of aggression, an unjust war of defense would involve resistance to the aggressor's just cause and not just the defense of individual lives.

In summary, it is still rather mysterious what traditional just war theorists have been assuming in their supposition that unjust combatants can satisfy the requirement of proportionality in the same way that just combatants can. If, as I have argued, unjust combatants can satisfy that requirement in only a narrow range of cases, and if, as just war theorists assert, the satisfaction of the proportionality requirement is a necessary condition of permissible conduct in war, it follows that in practice no unjust war can be fought in a permissible manner, that in general unjust combatants do wrong merely by fighting, and that because a just war can be fought entirely in a permissible manner, jus in bello cannot be independent of jus ad bellum.

\section{The Requirement of Discrimination}

The arguments I have advanced also challenge the third foundational tenet of the traditional theory: the requirement of discrimination. They do not challenge that requirement in its most generic formulation, which is simply that combatants must discriminate between legitimate and illegitimate targets. Rather, they challenge the assumption that the distinction between legitimate and illegitimate targets coincides with that between combatants and noncombatants. For I have argued that it is not permissible for unjust combatants to attack just combatants, except to prevent just combatants from engaging in wrongdoing that makes them morally liable to attack. For unjust combatants, therefore, there are, with few exceptions, no legitimate targets of belligerent action. In general, noncombatants and just combatants are alike impermissible targets for unjust combatants.

What, then, is the correct interpretation of the requirement? There must be one, for even if in general there are no legitimate targets for unjust combatants, there must, unless pacifism is true, be legitimate targets for just combatants, but also limits to what they may permissibly attack. That a just combatant's action may serve a just cause does not mean that he or she may treat anyone as fair game.

One possibility is that even if the traditional requirement is unacceptable in its application to unjust combatants, it is nevertheless correct in its application to just

\footnotetext{
${ }^{6}$ This is, of course, a controversial claim that I lack space to defend here, though I do so in a manuscript in progress called The Ethics of Killing: Self-Defense, War, and Punishment. I defend the claim against important objections in McMahan (2004).

黑 Springer
} 
combatants. It might be, in other words, that just combatants are permitted to attack unjust combatants but not to conduct intentional attacks against noncombatants. ${ }^{7}$ This view has, moreover, an obvious foundation in a more general and seemingly compelling principle. This principle is a significantly qualified variant of the principle rejected earlier that asserts the permissibility of defensive force. The qualified principle holds that, if other things are equal, it is permissible to use defensive force against anyone who poses an unjust threat. Because unjust combatants pose an unjust threat (except on those occasions when they are defending themselves or others against wrongful action by just combatants) but enemy noncombatants do not, it follows from the qualified general principle that enemy combatants are in general legitimate targets for just combatants but that enemy noncombatants are not.

This position has the clear advantage of being able to recognize the impermissibility of self-defense against what I have elsewhere called a Just Attacker - that is, a person who is justified in attacking another and whose victim lacks a right not to be attacked by him and is therefore not wronged by the attack. Thus, whereas the more orthodox view of Walzer and most others in the just war tradition has to assert that the conditions of war fundamentally alter the morality of defensive force, this alternative position holds that the same basic principle - the permissibility of defensive force against unjust threats - applies equally and without modification both in domestic society and in war. And although this alternative view is fundamentally antagonistic to the more orthodox view because it offers no justification for most acts of war by unjust combatants, it, or at least something very close to it, is not unfamiliar in the just war tradition. ${ }^{8}$

I will, however, argue against this alternative understanding as well, despite its greater plausibility. I will argue that even in its application to just combatants, the requirement of discrimination cannot take the relevant distinction to be that between combatants and noncombatants.

This alternative understanding of the requirement of discrimination asserts that it posing an unjust threat that makes a person morally liable to defensive force or, to put it another way, makes the person lack a right not to be attacked in self- or other-defense. I claim, by contrast, that posing an unjust threat is neither necessary nor sufficient for liability. It is possible to pose an unjust threat without being liable to attack and possible to be liable to attack without posing an unjust threat, and indeed without posing a threat at all.

How could it be that one could pose an unjust threat to another without losing one's right not to be attacked - that is, without it becoming permissible for one's potential victim to attack in self-defense? I believe - though I concede that the implications are counterintuitive - that one does not lose one's right not to be attacked by posing an unjust threat to another if one is in no way morally responsible for this fact.

Consider an example drawn from science fiction:

The Implacable Pursuer A person is drugged and kidnapped while sleeping by a villain who then implants a device in her brain that irresistibly directs her will to the task of killing you. As a result, she will implacably pursue your death until she kills you, at which time the device will automatically deactivate itself.

\footnotetext{
${ }^{7}$ I believe, contrary to the traditional assumption, that there can be rare instances in which both sides in a war have a just cause and are justified in fighting. For present purposes I leave it an open question what the requirement of discrimination should say about attacks by just combatants against just combatants in such cases.

${ }^{0}$ See, for example, Anscombe (1981), p. 53.
} 
Let us stipulate that the original person will continue to exist throughout the period in which her will is controlled by the device. Indeed it seems coherent to suppose that, while she pursues you, a part of her conscious mind could observe her own behavior with horror but be powerless to exert control over the movements of her body.

I claim that the Pursuer, who is what I call a Non-Responsible Threat, has done nothing to lose any rights or to make herself morally liable to attack. Although she is causally implicated in the threat to you, that is a wholly external fact about her position in the local causal architecture. It has no more moral significance than the fact that an innocent bystander might, through no fault of her own, occupy a position in the causal architecture that makes your killing her the only means by which you could save your own life. If you would not be permitted to kill the innocent bystander as a means of self-preservation, you are also not permitted to kill the Non-Responsible Threat in self-defense. For a NonResponsible Threat is morally indistinguishable from an innocent bystander. ${ }^{9}$ (There are lesser harms you could permissibly inflict on an innocent bystander as a means of selfpreservation. Whatever harms you would be permitted to inflict on an innocent bystander in order to save your life, you would also be permitted to inflict on a Non-Responsible Threat in self-defense.)

The claim that one may not kill a Non-Responsible Threat in self-defense is contrary to common sense. It is not, however, directly relevant to the requirement of discrimination or to the morality of war, since unjust combatants are almost invariably morally responsible at least to some degree for the unjust threats they pose. Nevertheless, the case of the Pursuer does suggest that moral responsibility is important to liability. If the Pursuer were in some measure responsible for the unjust threat she poses, that would establish an obviously relevant moral asymmetry between you and her and would constitute a sufficient basis for the permissibility of your killing her if that were necessary to defend your life.

We ought not to conclude, however, that it is a person's being responsible for posing an unjust threat that makes it permissible to use force against that person in order to eliminate the threat. For a person may be morally liable to such force simply by virtue of being morally responsible for an unjust threat, even if he does not himself pose the threat. Consider again the case of the Pursuer. Suppose that the person who programmed and implanted the mind-control device - call him the Initiator - has suffered an accident and is now bedridden and tethered to a respirator. You go to plead with him only to discover that he is powerless to stop the Pursuer. ${ }^{10}$ At that point, you see the approach of the Pursuer, who has followed you to the Initiator's house. You have only two options for saving yourself. One is to shoot the Pursuer as she approaches. The other is to flee in the Initiator's car. This car, however, is battery-powered and the only available battery is the one that is supplying power to the respirator. In order to flee the Pursuer, you must remove the power supply from the Initiator's respirator, thereby killing him.

What ought you to do: allow yourself to be killed, kill the Pursuer, who poses an unjust threat but is not responsible, or kill the Initiator, who now poses no threat but is morally responsible for the threat posed by the Pursuer? It would be permissible for you to allow

\footnotetext{
${ }^{9}$ A mistaken variant of this claim is defended in McMahan (1994a). A better argument is in McMahan (2002). Others who argue that there is no right of self-defense against a Non-Responsible Threat are Zohar (1993), Otsuka (1994) and Rodin (2002).

${ }^{10}$ I am indebted to Monsignor Stuart Swetland and to Richard Arneson for making me see the importance of this detail. If the Initiator could eliminate the threat to you, he could be regarded as continuing to pose the threat by having set it in motion and then refusing to stop it. For an ancestor of this kind of case that differs from it in that the person in the position of the Initiator remains a necessary cause of the threat, see Alexander (1985), p. 100.
} 
yourself to be killed but in the circumstances that is not morally required. The view that asserts the permissibility of defense against unjust threats implies that you may kill the Pursuer but not the Initiator. Intuitively, however, it seems that if you must kill one or the other to save your life, you must kill the Initiator rather than the Pursuer. Because the Initiator is the one who is morally responsible for the fact that someone must die, he should, as a matter of justice, bear the costs of his own voluntary and culpable action. (We can assume that, if you evade the Pursuer on this occasion, she can be subdued by the police and the device can then be removed from her brain.)

In summary, what the case of the Implacable Pursuer suggests is that posing an unjust threat is neither necessary nor sufficient for moral liability to force or violence that is necessary to eliminate the threat. Rather, what makes a person morally liable to force or violence that is necessary to eliminate an unjust threat is moral responsibility for initiating or sustaining the threat (or perhaps, in some cases, for failing to eliminate the threat).

\section{The Criterion of Liability and Its Application to Unjust Combatants}

This account of the basis of liability to defensive force has implications for the nature of the requirement of discrimination. If it is moral responsibility for an unjust threat that is the principal basis of liability to defensive (or preservative) force, it seems to follow that what makes a person a legitimate target in war is moral responsibility for an unjust threat. This assumes that permissible force in war always involves defense against an unjust threat; but it may be that there are some types of just cause for war that are not defensive, such as offensive action to recover territory or other goods that were lost to previous unjust aggression. To accommodate these possibilities, our claim should be broadened to assert that what makes a person a legitimate target in war is moral responsibility for an unjust threat or, more generally, for a wrong that provides a just cause for war. The requirement of discrimination should then hold that combatants must discriminate between those who are morally responsible for an unjust threat, or for a wrong that provides a just cause, and those who are not. It should state that while it is permissible to attack the former, it is not permissible intentionally to attack the latter - or if, more plausibly, we think that the requirement should not be absolute, it should state that there is a strong moral presumption against the permissibility of intentionally attacking those who are not responsible for an unjust threat or for a wrong that provides a just cause.

According to this understanding of the requirement of discrimination, all unjust combatants who are morally responsible for posing an unjust threat are legitimate targets of defensive or preservative attack by just combatants. This means that virtually all unjust combatants are legitimate targets because virtually all are moral agents, and because even those who are in rear areas or are asleep and are therefore not presently attacking nevertheless pose a threat by virtue of their participation in a continuing attack that has many phases coordinated over time.

It is important for understanding these claims to note that the understanding of "responsibility" employed here is eccentric. ${ }^{11}$ Responsibility - for an unjust threat, for instance - is often assumed to require some degree of culpability, which involves both fault in the act and fault in the agent. As I will use the term, however, responsibility does not presuppose or entail culpability. If a morally responsible agent - that is, an agent with the

\footnotetext{
${ }^{11}$ For further elucidation, see McMahan (2002), pp. 402-403.
} 
capacity for autonomous deliberation and action - creates an unjust threat through voluntary action that is wrongful but fully excused, she is to some extent responsible for that threat even though she is not blamable. ${ }^{12}$ In such a case there is fault in the act but not in the agent. I believe, moreover, that there can be responsibility even in the absence of fault in the act - that is, even when a person acts permissibly. If, for example, a person voluntarily engages in a permissible but foreseeably risk-imposing activity, such as driving a car, that person will be responsible if, contrary to reasonable expectation and through no fault on the part of the agent, that activity creates a threat or causes harm to which the victim is in no way liable. It is important to bear these points in mind; for it is sometimes thought that if we reject the view that the innocent in war are simply those who pose no threat, the alternative must be to accept that innocence means moral innocence, which contrasts with moral guilt or culpability. According to this latter view, it is culpable responsibility for an unjust threat that is the basis of moral liability to defensive force. This, however, is not the view defended here. ${ }^{13}$

Unjust combatants pose an unjust threat. But they may, as we noted earlier, have one or more of a variety of excuses: for example, they may have been deceived, manipulated, indoctrinated, or coerced or compelled by threats, or perhaps they just believed, reasonably but mistakenly, in the moral authority of their government. In some cases, these excusing conditions will be strong enough to absolve an unjust combatant of all culpability for participation in an unjust war. But conditions of this sort are never sufficient to absolve him of all responsibility for his participation, or for the unjust threat he poses. Thus, even if he is morally innocent, he is not innocent in the sense that is relevant to the requirement of discrimination. Only the absence of a capacity for moral agency could absolve him of all responsibility for his action and thus make him innocent in the latter sense. ${ }^{14}$

Moral responsibility, however, is a matter of degree and the degree of an unjust combatant's responsibility for posing an unjust threat is reduced by such excuses as nonculpable ignorance and duress. And it is reasonable to assume that the extent to which a person is morally liable to defensive force varies with the degree of his responsibility for the existence of, or for posing, an unjust threat. But how are we to understand the idea that liability varies in degree? It seems that either a person is a legitimate target or he is not; either it is permissible to attack him or it is not.

A person becomes a legitimate target in war by being to some degree morally responsible for an unjust threat, or for a wrong that provides a just cause for war. But there are various constraints, such as minimal force and proportionality, that apply even to attacks on legitimate targets. The way that variations in the degree of a person's liability to defensive force are manifested is in variations in the strength or stringency of these constraints. For example, a level of harm that it might be proportionate to inflict on unjust combatants who are culpable might not be proportionate if inflicted on unjust combatants known to be largely innocent.

It may be objected that, while this might be true in principle, it is irrelevant in practice since it is normally impossible to know, of any particular unjust combatant, the degree to

\footnotetext{
${ }^{12}$ Since writing the longer version of this paper, I have modified my view about the conditions for moral responsibility for an unjust threat. I now believe that in cases in which a morally responsible agent poses an unjust threat through voluntary action but was not engaging in a risk-imposing activity and could not have foreseen the he would pose a threat, he is not responsible for the threat. See McMahan (2005).

${ }^{13}$ It is, however, the view I defended in both "Self-Defense and the Problem of the Innocent Attacker" (McMahan, 1994a) and "Innocence, Self-Defense, and Killing in War" (McMahan, 1994b).

${ }^{14}$ Again, my view is no longer quite so strong. See Footnote 12.

Springer
} 
which he is morally responsible for the unjust threat he poses or for whatever grievance constitutes the just cause for war. This is largely true. But, as in the case of individual selfdefense, reasonable agents in war have to act on the basis of presumptions that are as well grounded as possible in the circumstances. And there is occasionally good reason to presume that one group of unjust combatants bears a greater degree of liability than another. In the first American war against Iraq, for example, all Iraqi combatants were unjust combatants because they fought to resist the reversal of their country's unjust invasion and occupation of Kuwait. Yet some bore a greater degree of responsibility than others. It was reasonable to assume that members of the Iraqi Republican Guard, a highly-paid, elite volunteer force loyal to the regime, were responsible for their action to a higher degree than poorly armed conscripts who had been compelled by threats to themselves and their families to take up positions in the desert. I believe that the proportionality requirement applied differently to attacks against these different groups. Forces of the coalition against Iraq were entitled to inflict as much harm on the Republican Guard as was necessary to eliminate the threat the guard posed to them; but they may have been morally required to accept greater risks to themselves to reduce the harm inflicted on conscripts, in something like the way that combatants are obliged to accept greater risks in order to minimize incidental harm to innocent civilians.

More generally, it is true of most unjust combatants that their conduct is excused to varying degrees by the sorts of consideration Walzer mentions in arguing that they are not criminals and that these excuses diminish their liability to varying degrees. This is in itself an important consideration that affects the way that the requirements of minimal force and proportionality apply to the use of force even in a just war. Even just wars should be fought with more restraint than might be required if it were reasonable to assume that unjust combatants were criminals or villains rather than the victims of duress and delusion.

\section{Noncombatant Liability}

Recall that the example of the Initiator offers intuitive support for the claim that one need not pose an unjust threat or currently be part of that threat in order to be morally responsible for it. And it should be obvious that in war there are some who occupy a position analogous to that of the Initiator: namely, noncombatants who bear significant responsibility for initiating or sustaining an unjust war, or for the wrong whose redress is the just cause for war. Some of these may be responsible to a greater degree than any combatant. In 1954, for example, executives of the United Fruit Company persuaded the Eisenhower administration to organize and direct a coup that overthrew the democratic government of Guatemala and installed a new regime that returned to the company some uncultivated lands that had been nationalized in an effort to aid the peasants. This is a paradigm of an unjust war and it is reasonable to suppose that the executives bore at least as great a degree of responsibility for the killing and the violation of national self-determination as the soldiers who carried it out. ${ }^{15}$ According to the understanding of the requirement of discrimination I have advanced which I will refer to as the responsibility criterion - the executives were liable; they were legitimate targets. If attacking them would have been as effective as attacking soldiers in preventing the coup, the responsibility criterion implies that, other things being equal, it would have been permissible to attack them, and that that might have been preferable to attacking combatants, particularly if it would have meant that fewer people had to be killed.

\footnotetext{
${ }^{15}$ For a brief but more detailed description of this episode, see McMahan (1985), pp. 13-14.
} 
The responsibility criterion denies both the permission and the prohibition asserted by the traditional requirement. Because it claims that it is in general impermissible for unjust combatants to attack just combatants, it denies the traditional claim that all combatants are permissible targets; because it claims that some noncombatants are permissible targets, it denies the traditional prohibition of intentional attacks on noncombatants.

Perhaps some may not find it appalling to suppose that in the case of United Fruit, certain civilians could be morally liable to attack. But for most people, the general suggestion that civilians can be legitimate targets in war will seem pernicious. The best way to address this understandable reaction is to respond to a couple of the more obvious objections to the responsibility criterion. ${ }^{16}$

One worry is that because moral responsibility is a matter of degree, it is difficult to identify a lower bound or threshold for responsibility for an unjust threat or other grievance that provides a just cause for war. Because of this, the responsibility criterion threatens to be utterly promiscuous in its assignment of liability in war. For in an unjust war many voters and perhaps all taxpayers must surely bear some degree of responsibility for their country's action. But if the responsibility criterion implies that a great many or even most ordinary citizens in a country fighting an unjust war are legitimate targets, it can hardly be regarded as a principle of discrimination at all.

The first part of the reply to this objection is that the same objection applies in a more seriously damaging way to the traditional requirement of discrimination. According to the traditional requirement of discrimination, noncombatants are those who are not threatening, who do not contribute to the threat posed by their country. The problem of drawing the line between those who contribute to the threat and those who do not is a familiar one in the just war literature. The typical response is to try to find a basis for drawing the distinction between combatants and noncombatants in a way that limits liability in war to soldiers, those who directly supply them with the instruments of war (including, perhaps, workers in munitions factories, but only while they are at work), and those who occupy positions in the military chain of command. ${ }^{17}$ It is sometimes said, for instance, that if a person who makes a material contribution to the war is doing the same thing she would be doing if war were not in progress, she is not a combatant. But such criteria of combatant status never correspond to the tradition's own generic notion of a combatant, which is simply the notion of a person who poses a threat or contributes to the threat his country poses - the latter clause being necessary for the inclusion of military personnel who occupy roles that do not involve participation in combat or the firing of weapons. And the class of those who contribute, even quite directly, to their country's war effort is in fact considerably more extensive than the class of military personnel. It includes, for example, doctors who heal wounded soldiers and return them to combat.

So the line-drawing problem is not unique to the responsibility criterion. But on what basis can I claim that this problem is more seriously damaging to the traditional requirement of discrimination? The reason is that on the traditional view, the criterion of liability is allor-nothing: either one is a combatant or one is not, a legitimate target or not a legitimate target. There are no degrees of liability. The only constraints on attacking legitimate targets

\footnotetext{
${ }^{16}$ Some of these responses indicate ways in which the account of the morality of war I have developed in this paper is superior to the cruder account I advanced in "Innocence, Self-Defense, and Killing in War" (McMahan, 1994b), which invites similar objections but cannot answer them in the ways suggested here.

${ }^{17}$ For representative examples, see Nagel (1985), pp. 69-70, Walzer (1977), pp. 144-146, Finnis et al. (1987), pp. 86-90, and Oderberg (2000), pp. 217-219.
} 
(combatants) are the requirements of necessity, minimal force, and proportionality, and the proportionality calculation takes account of only two variables: the gravity of the threat that the combatant poses and the magnitude of the harm that defensive force would inflict. According to the responsibility criterion, by contrast, the proportionality calculation has to take account of three variables: The gravity of the threat, the amount of harm that would be inflicted, and the degree of the potential target's moral liability. Thus a use of force that would be proportionate according to the traditional requirement of discrimination might be disproportionate according to the responsibility criterion if the person at whom it would be directed was only weakly responsible for the threat (or other wrong) that was the basis of his liability. In short, even though the responsibility criterion (like the traditional requirement) implies that many civilians are permissible targets in principle, in the vast majority of cases a civilian's degree of liability will be so low that to attack him or her militarily would be wholly disproportionate. While voters or taxpayers might be morally liable, for example, to the effects of certain kinds of economic sanction, they would not be appropriate targets for military force. This conclusion is reinforced by the fact that, in contrast to unjust combatants, even morally responsible noncombatants normally make only a very slight causal contribution to their country's unjust war, so that attacking them would do little to diminish the threat their country poses or to advance the just cause.

A second objection is that, just as it is normally impossible to have accurate information about an unjust combatant's responsibility for the threat he poses, so it is normally impossible to have detailed information about whether and to what extent a particular noncombatant is responsible for her country's unjust war. Again, this is true. But it does not show that noncombatants cannot be liable, but only that just combatants can seldom know which ones are responsible or to what extent they are responsible. And this drastically restricts the practical significance of the responsibility criterion's implication that some noncombatants may be legitimate targets in war. For, while a few noncombatants may bear a high degree of responsibility for their country's unjust war and many may be responsible to a much weaker degree, there are also many others who are not responsible at all. Because one cannot normally distinguish among the highly responsible, the minimally responsible, and those who are not responsible at all, just combatants should in general err on the side of caution by acting on the presumption that noncombatants are innocent - that is, devoid of responsibility for their country's unjust war (just as just combatants may act on the presumption that unjust combatants are responsible for the threat they pose). And even if, on some occasions, just combatants were to have sufficient information to be able to distinguish between responsible and nonresponsible noncombatants, the responsible ones would normally be intermingled among the nonresponsible, making it impossible to direct force, or even economic sanctions, against the responsible ones only. And this is a further reason why military action can very rarely if ever be proportionate against civilian targets. In this respect, attacks on civilian populations are again importantly different from attacks against groups of unjust combatants, for all of the latter are (or may reasonably be presumed to be) to some degree liable to defensive force.

\section{The Laws of War}

Doubtless most readers retain a strong sense that opening the door to intentional attacks on noncombatants is profoundly dangerous. As with the other three objections I have canvassed, this is true. It is important that combatants should always experience deep inhibitions against attacking noncombatants. As I have argued, it is very seldom 
permissible, even according to the responsibility criterion, to attack noncombatants. Yet the temptation to attack them is very strong, both among those with political grievances who lack military power and among those who control powerful military forces. Because most soldiers, just and unjust alike, believe their cause is just, they will be strongly disposed to kill civilians if they believe that it is permissible to kill enemy civilians who are responsible for an unjust war. It therefore seems better to discourage even those few attacks on noncombatants that could in principle be morally justified.

This suggests that there is indeed a role for the traditional requirement of discrimination. Although it is false as a criterion of moral liability to attack in war, it ought nevertheless to be upheld as a convention to which all combatants are bound. Thus far in this essay I have focused on what I will refer to as the "deep" morality of war: the criterion of moral liability to attack, the relation between just cause and the jus in bello requirement of proportionality, and so on. But there is another dimension to the morality of war that I have not explored: the laws of war, or conventions established to mitigate the savagery of war. It is in everyone's interests that such conventions be recognized and obeyed. But, although the conventions have their point in considerations of consequences, they can have a role even in a nonconsequentialist account of the morality of war, such as the one I offer here. Given that general adherence to certain conventions is better for everyone, all have a moral reason to recognize and abide by these conventions. For it is rational for each side in a conflict to adhere to them only if the other side does. Thus if one side breaches the understanding that the conventions will be followed, it may cease to be rational or morally required for the other side to persist in its adherence to them. A valuable device for limiting the violence will thereby be lost, and that will be worse for all.

It is important to understand that the account I have developed of the deep morality of war is not an account of the laws of war. The formulation of the laws of war is a wholly different task, one that I have not attempted and that has to be carried out with a view to the consequences of the adoption and enforcement of the laws or conventions. It is, indeed, entirely clear that the laws of war must diverge significantly from the deep morality of war as I have presented it. Perhaps most obviously, the fact that most combatants believe that their cause is just means that the laws of war must, at least for the most part, be neutral between just and unjust combatants, as the traditional theory insists that the requirements of jus in bello are. Consider, for example, the question of punishment in the aftermath of a war. I have argued that according to the deep morality of war, unjust combatants in general cannot obey certain requirements of jus in bello and therefore act wrongly by participating in an unjust war. While many are fully excused, some may be culpable to varying degrees, and some may even deserve punishment, even if they have confined their attacks to military targets. But it would be counterproductive and indeed disastrous to permit the punishment of ordinary soldiers merely for their participation in an unjust war. This is so for several reasons.

First, it is simply impossible for one country, or even an international body, to provide fair trials for all the members of an army. Second, there is the problem of "victor's justice": the winning side will declare its war to have been just and will be tempted to seek vengeance against vanquished soldiers under the guise of punishment. Finally, if all combatants have to fear this fate, they may be deterred from surrendering; and it is irrational to establish incentives to protract wars rather than to terminate them.

It is, however, important to be able to punish just combatants who act wrongly in the way they conduct a war. The solution, it seems, must be to reserve punishment for infractions of the conventions or laws of war, which must be neutral between just and 
unjust combatants, rather than for violations of the deeper principles of jus in bello, which are not neutral.

It is possible that the traditional rules of jus in bello coincide rather closely with the laws that would be optimal for regulating conduct in battle. These rules have evolved over many centuries and have been refined, tested, and adapted to the experience of war as the nature of war has itself evolved. They may, in particular, be well suited to the regulation of the conduct of war in conditions in which there are few institutional constraints, so that the restraining effects have to come from the content of the rules rather than from institutions in which the rules might be embedded. ${ }^{18}$

It is also possible that these rules are not ideal. They are the products not only of modern battlefields but also of ancient chivalric engagements, religious wars, and Medieval Catholic philosophy. (Just war theory is unique in contemporary practical ethics in two respects. It is widely and uncritically accepted and differs very little in content from what Western religious thinkers have believed from the Middle Ages to the present.) The account of the deep morality of war I have sketched provides a basis for the reevaluation of the rules we have inherited. Ideally we should establish laws of war best suited to get combatants on both sides to conform their action as closely as possible to the constraints imposed by the deep morality of war. Yet it is dangerous to tamper with rules that already command a high degree of allegiance. The stakes are too high to allow for much experimentation with alternatives.

There are, moreover, objections to the idea that we can distinguish between the deep morality of war and the laws of war. One such objection has been forcefully stated by Walzer: "No limit is accepted simply because it is thought that it will be useful. The war convention must first be morally plausible...; it must correspond to our sense of what is right." 19

This may not be a problem for some of the conventional laws of war. The idea that it is wrong to attack noncombatants, for instance, already corresponds to most people's sense of what is right. Moreover, it does seem that people can accept limits, even in war, on the ground that respect for these limits serves everyone's interests. It is not obvious, for example, that poison gas is inherently more objectionable morally than artillery, provided that its use is confined to the battlefield; yet the convention that prohibits its use is widely obeyed, mainly because we all sense that it would be worse for everyone, ourselves included, were the taboo to be breached.

Suppose, however, that I am wrong about this and that, in general, if combatants are to be sufficiently motivated to obey certain rules in the conduct of war, they will have to believe that those rules really do constitute the deep morality of war. If it is imperative to get them to respect certain conventions, must we present the conventions as the deep morality of war and suppress the genuine deeper principles? Must the morality of war be self-effacing in this way? ${ }^{20}$ I confess that I do not know what to say about this, though my inclination is to think that what is most important is not that the correct account of the morality of war should meet the publicity condition, or that combatants not be deceived, but that wars, when inevitable, should be fought as decently and with as little harm, especially to the innocent, as possible.

\footnotetext{
${ }^{18} \mathrm{I}$ am indebted here to Allen Buchanan.

${ }^{19}$ Walzer (1977), p. 133.

${ }^{20}$ I have been helpfully pressed to confront this and related problems by Charles Beitz, Gilbert Harman, Philip Pettit, and Peter Singer. They will be disappointed by my anemic and noncommittal response.
} 
One further objection to distinguishing between the deep morality of war and the laws of war is that there are bound to be circumstances in which the deeper morality and the conventions will conflict - for example, when morality requires an attack on noncombatants while the conventional requirement of discrimination forbids it. How ought such conflicts to be resolved? In order for morality to require the violation of the convention in a particular case, it must take into account not only the positive reasons for attacking noncombatants but also the effect that the violation of the convention would be likely to have on general respect for the convention. For it is widely accepted that the violation of a convention by one side tends to release the other side from its commitment to respect the convention. If, however, this consideration is factored in and morality still requires the violation of the convention, it seems that the convention ought to be violated. Yet there is so much scope for self-deception in these matters that this is a conclusion that one ought never to accept with complacency.

If, despite these problems, it is right that there must be laws of war that diverge from the deep morality of war, then war is normatively governed by two sets of principles that operate at different levels. It may seem, however, that it is really the conventions that must be action-guiding in the conduct of war and, if so, that raises the question whether the deeper morality of war has any practical significance at all. Are the judgments it issues of merely academic interest?

I think not. If nothing else, the deep morality of war is a guide to individual conscience. It demands of potential volunteers, potential conscripts, and active military personnel that they consider with the utmost seriousness whether any war in which they might fight is just and to refuse to fight unless they can be confident that it is. The effects of this demand are hard to predict. It might simply prompt governments to become ever more subtle and clever in the lies they tell their citizens. If so, it is a corollary of the account I have offered that greater efforts must be made to ensure openness in government. Yet I think that the main effect would be to make it harder for governments to fight unjust wars.

\section{References}

Alexander, L. (1985). Self-Defense and the Killing of Noncombatants. In Beitz, Charles R. et al. (Eds.) International Ethics. Princeton: Princeton University Press, pp. 98-105.

Anscombe, E. (1981). Ethics, Religion, and Politics: Collected Philosophical Papers, vol. 3. Minneapolis: University of Minnesota Press.

Finnis, J., Boyle, J., \& Grisez, G. (1987). Nuclear Deterrence, Morality, and Realism. Oxford: Oxford University Press.

McMahan, J. (1985). Reagan and the World: Imperial Policy in the New Cold War. New York: Monthly Review Press.

McMahan, J. (1994a). Self-Defense and the Problem of the Innocent Attacker. Ethics 104, pp. $252-290$.

McMahan, J. (1994b). Innocence, Self-Defense, and Killing in War. Journal of Political Philosophy 2, pp. $193-221$.

McMahan, J. (2002). The Ethics of Killing: Problems at the Margins of Life. New York: Oxford University Press.

McMahan, J. (2004). War as Self-Defense. Ethics and International Affairs 18, pp. 75-80.

McMahan, J. (2005). The Basis of Moral Liability to Defensive Killing. Philosophical Issues 15, pp. 386-405.

McMahan, J., \& McKim, R. (1993). The Just War and the Gulf War. Canadian Journal of Philosophy 23, pp. 501-541.

McPherson, L. (2004). Innocence and Responsibility in War. Canadian Journal of Philosophy 34, pp. 485-506.

Nagel, T. (1985). War and Massacre. In Beitz, Charles R. et al. (Eds.) International Ethics. Princeton: Princeton University Press pp. 53-74. 
Oderberg, D. (2000). Applied Ethics. Oxford: Blackwell.

Otsuka, M. (1994). Killing the Innocent in Self-Defense. Philosophy and Public Affairs 23, pp. 74-94.

Rodin, D. (2002). War and Self-Defense. Oxford: Clarendon Press.

Sidgwick, H. (1891). The Elements of Politics. London: Macmillan.

Walzer, M. (1977). Just and Unjust Wars. Harmondsworth: Penguin.

Zohar, N. (1993). Collective War and Individual Self-Defense: Against the Conscription of "Self-Defense." Political Theory 21, pp. 606-622. 